\title{
Evaluating and comparing brand equity of Iranian and South Korean home appliance brands in the view of Tehran bazaar retailers
}

\author{
${ }^{1}$ Gholamreza Jandaghi, ${ }^{2}$ Hossein Safarzadeh, ${ }^{3}$ Alireza Amini, ${ }^{4}$ Seddigheh Bahiraei \\ ${ }^{1}$ University of Tehran, Qom College, Iran, Email: jandaghi@ut.ac.ir \\ ${ }^{2}$ Islamic Azad University, Iran \\ ${ }^{3}$ Master in Business Management, University of Tehran- Qom College, Iran \\ ${ }^{4}$ Master in HRM University of Tehran- Qom College, Iran
}

\begin{abstract}
Home appliance market is, inter alia, a market where the brand equity is highly important. Today, brands of South Korean corporations such as Samsung and LG have penetrated the market broadly and have caused threats for goods produced by Iranian brands. Therefore, we evaluate the differences and compare the Iranian and Korean home appliance brand equities in present study. To achieve to evaluate the differences and compare the Iranian and Korean home appliance brand equities, 5 minor hypotheses were devised based on research conceptual model in the format of research major hypothesis in which Wilcoxon statistical test was used to support or refuse such hypotheses. The investigations were continued by selecting three Iranian brands which had the highest market share in three goods of refrigerators, TV sets and washing machines. By using Likert's seven-item scale, a questionnaire was devised to collect data and its validity and reliability were confirmed by elites' approval and 0.95 chronbach alpha. Research statistical population consisted of all home appliance retailers in Tehran 22 boroughs (about 900 shops). 206 shops were selected as the sample by using Cluster sampling method. Research hypotheses were tested in terms of product types and overall home appliances. In all tests excluding difference hypothesis on tendency to pay overprice for Iranian and Korean brands in washing machines, all hypotheses were supported by $95 \%$ confidence level. Then, the brand equities were ranked by Freedman's test for all three goods and finally, the analytical diagram to show the impacts of each research model elements on expressing the difference between Iranian and Korean special brands was drawn.
\end{abstract}

Keywords: brand equity, brand association, loyalty to brand, home appliance.

\section{INTRODUCTION}

Brand equity is a valuable intangible asset for many successful companies in marketplace competition (Voleti, 2008).The brand equity generates a type of added-value for products which help companies' long term interests and capabilities (Chen, 2008). It is not so necessary to emphasize on the fact that the brand is a capital asset. In fact, brand is the living blood of companies in many sectors. Although factories and human force may be destroyed, brand remains(Cupferer, 2006). It is a name whose background among people is a value of sustainable asset. Establishing strong brand is a strategic priority for many companies since general beliefs indicate that powerful brands can be a strength point and a competitive advantage for companies in their target markets. Therefore, brand distinguishes product from a similar one and penetrates into the way of consumers' perception and cognition. When brand
Elements are ideal in consumers' minds, brand equity is deemed positive and it is considered as negative if it is not ideal in their minds (Laboy, 2005). This competitive advantage is seen in the format of product ideal price, increasing the productivity of marketing strategies, increasing profit margin and cash flow, rising in demand and customers' satisfaction, facilitating brand expansion, bargaining power, less risk-taking than rivals(Bekhradi, 2009), entry-barriers, and retaining customers, reducing customers' gaining costs and value-generation for shareholders(Laboy, 2005). Positive brand associations in customers' minds would be stronger and more sustainable in general. Therefore, companies should make appropriate investments to establish and manage brand properly, The first step to manage brand is to evaluate its value in market and then, it should be compared to the values of other existed brand equities in the market especially the brands of goods with greater market share in 
order to determine the strengths or weaknesses of products or companies and in order than companies can compete more strongly in future.

Brands can be the distinguishing symbol of those products and services in which such symbols are observable when they are delivered. More complicated and riskier markets, more complicated and important brand driving forces that play vital role in the success of corporations. Therefore, it is necessary to manage brands strategically and to establish them by considering their special values(Agarwal \& Rao,1996). Increase in customeroriented brand equity can lead into more income, lower costs and, finally, more profits for manufacturers(Keller, 1993).

Home appliance market is, inter alia, a market where brand equities are highly important and customers' decisions are too sensitive in such market since, in one hand, home appliance is considered as sustainable goods and consumer wants to use for several years and, on the other hand, consumer should pay a relative high price. Thus, he/she tries to evaluate the options carefully to achieve the highest ideality. The brand equity is a tool which helps consumer in such situations.

Nowadays, if someone passes Tehran home appliance bazaar, he/she perceives that brands of Korean companies like Samsung and LG have broadly penetrated into the market which is a threat against domestic goods. During their attendance in the market, these companies have been able to pay more attention than other firms to the interests and tastes of Iranian consumers and have acquired higher market share through the compatibility of their merchandises. Therefore, the present paper evaluates the home appliance brand equity in Iran compared to Korean brands in order to determine the competitive gap between Iranian and Korean home appliance industry.

The necessity of execution and research objects: The necessity and importance of brand equity refers to the importance of brand in companies' marketing strategies. brand equity plays a strategic and significant role in acquiring competitive advantage and strategic management decisions. Brand equity a proper benchmark to evaluate the long term impacts of marketing decisions when it is measured carefully (Simon, 1993). Branding helps companies to stabilize themselves in future strategically and compete effectively with global giants that have dominated global markets. Anyhow, the expansion of successful brand is not easy. Brand is not established quickly since most companies lack proper experience or necessary knowledge to step this route(Temporal, 2003).

Today, those companies which operate in global markets owe more than half of their sale success particularly among consumers in developing countries - to their global brand. Perhaps, the quality and services provided by domestic firms to customers are similar to foreign ones but consumers are more tended to brands like Samsung and LG(Seyyed javadein, 2007).

Therefore, it is necessary that companies assess their brand among their customers in order to grow and expand their participation in global markets and compare it to brand equity of those companies which possess the highest share in competitive markets in order to devise their marketing strategies toward a strong brand in the market and their competition. So, it is attempted in this research to achieve following goals through evaluating domestic home appliance brand equities and comparing it to the brand equities of Korean counterpart products.

Main Object: Evaluating and comparing brand equity of Iranian and Korean home appliance in the view of Tehran bazaar retailers.

\section{Minor Objects}

1. Evaluating and comparing attitudes to Iranian and Korean home appliance brand.

2. Evaluating and comparing the associations of Iranian and Korean home appliance brand.

3. Evaluating and comparing the image of Iranian and Korean home appliance brand.

4. Evaluating and comparing loyalty to Iranian and Korean home appliance brand.

5. Evaluating and comparing the tendency to extra payment for Iranian and Korean home appliance brand.

Research theoretical framework: Brand equity is a measure by which brand power is gauged. When this term emerged in marketing journals since 1980, paramount methods were introduced for evaluation and estimation. The methods to evaluate brand equity are either financial or based on consumer's behavior. Typically, financial evaluations are based on brand price or an alternative of brand. For instance, based on the theory that stock market reflects future reactions to brand, Simon and Sullivan 
used changes in the stock prices to calculate brand value(Simon and sullivan, 1993). In another study, Mahajan et al introduced brand potential value as a determinant of Brand equity for applied usage in companies' purchases(Rahman seresht, 2006).

In marketing literature, brand equity is being operational in two manners: those who have considered consumer's perceptions such attitude on brand, brand awareness, brand association and conceived quality; and those who have addressed consumer's behaviors such as loyalty to brand, extra payment, etc. Both methods calculate brand equity via consumer's perspective(Bahreinizadeh, 2006).

According to Aaker, brand equity is achieved by brand association, loyalty to brand, brand awareness, conceived quality and other assets shown in figure 1 (Aaker, 2006).

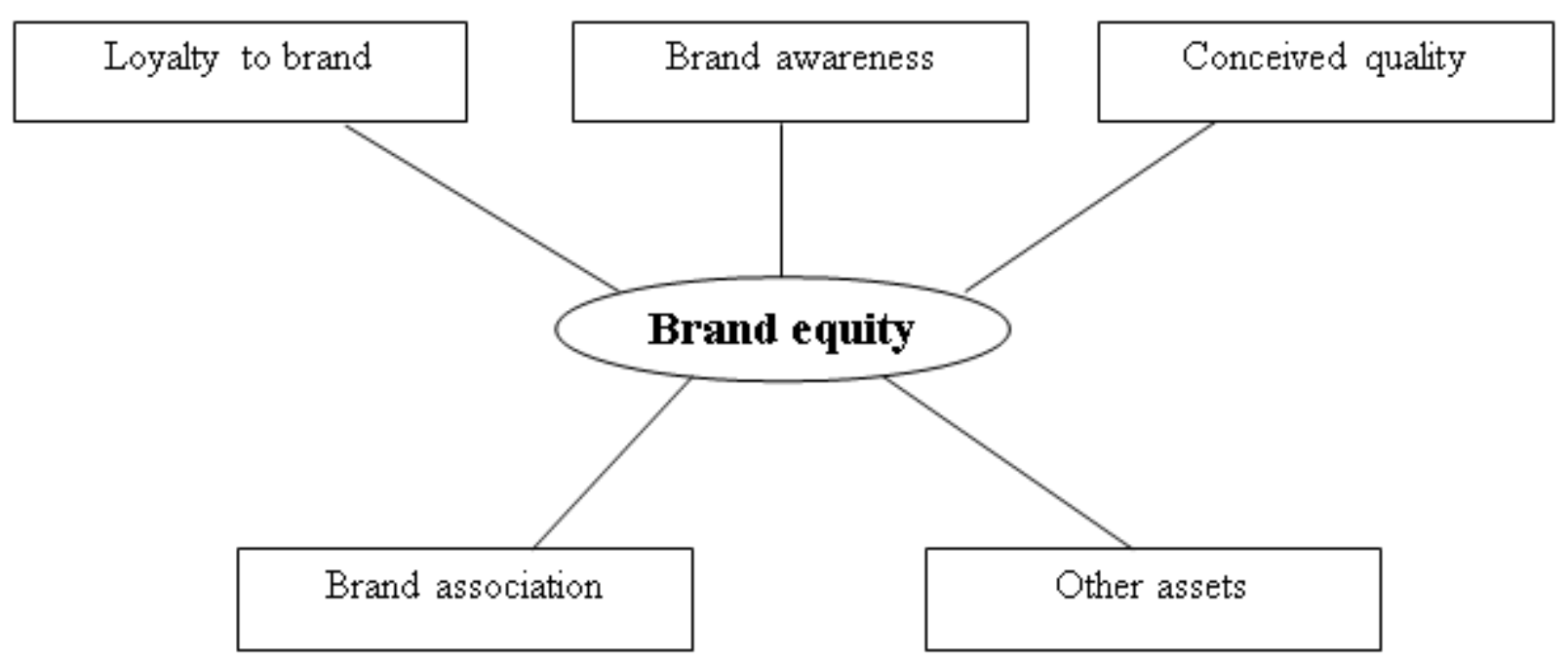

Figure 1: brand equity model based on Aaker's insight

Research conceptual model: In a paper titled "a model to brand equity in consumers' views: a research in Bushehr and Fars provinces", Hussein Rahman Seresht clarified a model to brand equity in which 5 factors to measure brand equity are introduced based on two perceptional and behavioral aspects. Three factors regarding attitude on brand, brand image and brand association are perceptional and two factors on loyalty to brand and extra payment for brand products are behavioral. These factors and the way of their relations are shown in figure 2 .

In present paper, measuring the elements of this model as a conceptual model is used to evaluate and compare the value of home appliance brand equity. 


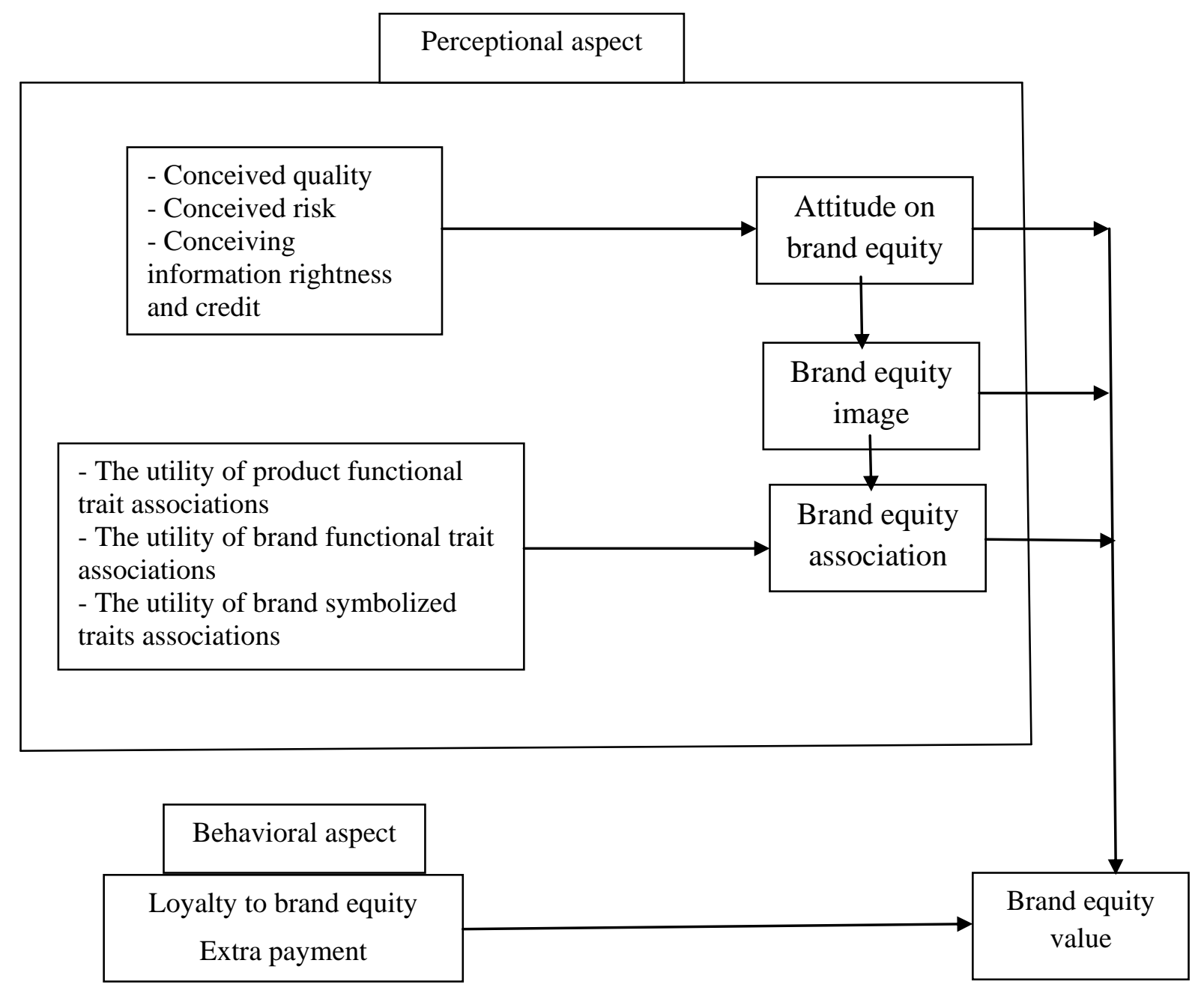

Fig 2: brand equity conceptual model

\section{Research hypotheses}

Based on research conceptual model and framework as well as factors which should be considered to measure brand equity, following hypotheses are devised:

\section{Major hypothesis:}

Brand equity of Iranian home appliance has low quality compared to Brand equity of Korean home appliance.

\section{Minor hypotheses:}

1. Attitude on Iranian home appliance brand has lower quality than Korean home appliance brand.
2. Iranian home appliance brand association has lower utility than Korean home appliance brand.

3. Iranian home appliance brand image has lower quality than Korean home appliance brand.

4. Loyalty to Iranian home appliance brand is lower quality than Korean home appliance brand.

5. Tendency to extra price payment for Iranian home appliance is lower than Korean products.

\section{METHODOLOGY}

Present study is a descriptive survey which seeks to expound the aspects, characteristics, traits, limitations and deficiencies of Iranian home appliance 
brand equity compared to Koreans ones. To gather statistical data, 3 Korean brands (Samsung, LG and Daewoo) were identified and selected by studying market information resources and the documents of home appliance syndicate. Then, three Iranian brands with similar products to Korean brands as well as the highest share in the market were selected as follows:

1. Refrigerator: Emersun; Snowa, Yakhsaran
2. TV sets: Snowa; Sanam, Pars

3. Washing machine: Absal; Snowa; Pakshuma Afterwards, a questionnaire by Likert's seven-item scale was devised to measure the equity of each selected brand. Its validity was confirmed by marketing experts and its reliability was supported by 0.95 chronbach alpha through the initial data of 30 questionnaires. Table 1 outlines achieved alpha ratio from questionnaire items in terms of research model variables.

Table 1: computing alpha ratio in terms of research conceptual model

\begin{tabular}{|c|c|c|c|c|c|c|}
\hline Variables & Association & Extra payment & Validity & Risk & Quality & Loyalty \\
\hline Chronbach alpha & 0.915 & 0.709 & 0.821 & 0.796 & 0.787 & 0.909 \\
\hline
\end{tabular}

\section{Population, sample size and sampling method}

Since present study attempts to compare the Iranian and Korean brand equities, its populations consists of those home appliance retailers and sellers who have worked with both Iranian and Korean home appliances in order to achieve a more precise evaluation and comparison. Thus, according to the opinion of home appliance syndicate, it was clarified that in all Tehran 22 boroughs, there are over 1300 home appliance retailers of whom 400 shops sell single brand products. This figure was deducted and finally 900 shops were considered as research population.

To determine sample size, average sample size formula was used due to the clarification of population volume. The highest variance was 0.25 and 206 retailers were computed in 0.05 determination level and 6\% error.

Single-step cluster sampling was used in order that research statistical sample represents the community properly. In this line, statistical community was clustered into 5 geographical areas: northeast, northwest, central, southeast and southwest. Boroughs 2, 4, 11, 12, 15, 19 and 20 were selected by considering the volume of retailers in such regions.

Based on the initial random sampling among 30 shops, 13 ones filled the questionnaire for washing machine, 11 ones for refrigerator and 6 ones for TV sets in terms of their activities. According to this pretest, 6,5 and 3 questionnaires were distributed for washing machines, refrigerators and TV sets among retailers respectively.
197 of total 206 distributed questionnaires were returned of which 4 questionnaires were useless. Finally, 193 questionnaires were analyzed which included 41 questionnaires for TV sets, 68

$$
n=\frac{N \cdot Z_{\frac{\alpha}{2}}^{2} \cdot \sigma^{2}}{(N-1) d^{2}+Z_{\frac{\alpha}{2}}^{2} \cdot \sigma^{2}}=\frac{900 \times 1.96^{2} \times 0.25}{(900-1) \times 0.06^{2}+1.96^{2} \times 0.25} \geq 206
$$

questionnaires for refrigerators and 84 questionnaires for washing machine.

In this section, we address to research hypotheses. Initially, minor hypotheses are analyzed in terms of products and then the major hypothesis is represented. In all steps, SPSS software is used for calculations.

Kolmogorov - Smirnov (K - S) test: before evaluating research hypotheses, we measure the normality of gathered data by using $\mathrm{K}-\mathrm{S}$ test.

$H_{0}$ : Variable distribution is normal.

$H_{a}$ : Variable distribution is not normal.

Result: the $Z$ statistic of test at 0.05 determination level is located in statistical null hypothesis level for research variables in all three products. Thus, 95\% normal distribution for all research model variables in three products is calculated.

\section{Minor hypotheses}

To test research hypotheses, Wilcoxon test is used and the results for each product are sown in table 2 . The statistical hypotheses of Wilcoxon test are as follow:

$$
\begin{aligned}
& H_{0: \mu_{\text {Iran }}}=\mu_{\text {Korea }} \\
& H_{a:}: \mu_{\text {Iran }}<\mu_{\text {Korea }}
\end{aligned}
$$


Table 2: the results of Wilcoxon test and its statistic regarding 5 research minor hypotheses in terms of three products and in overall home appliance

\begin{tabular}{|c|c|c|c|c|c|c|c|}
\hline $\begin{array}{l}\frac{ \pm}{0} \\
\frac{3}{0} \\
\frac{0}{2}\end{array}$ & Hypotheses & Korea - Iran & $\begin{array}{c}\text { Quanti } \\
\text { ty }\end{array}$ & $\begin{array}{c}\text { Average } \\
\text { rank }\end{array}$ & $\begin{array}{l}\text { Total } \\
\text { ranks }\end{array}$ & $\mathbf{Z}$ & $\begin{array}{l}\text { Asymp. } \\
\text { Sig (2- } \\
\text { tailed) }\end{array}$ \\
\hline \multirow{5}{*}{$\begin{array}{l}\stackrel{\Phi}{\Phi} \\
\infty \\
\gtrless\end{array}$} & $\begin{array}{l}\text { Difference of attitude } \\
\text { on Iranian and } \\
\text { Korean brand }\end{array}$ & $\begin{array}{l}\text { Negative ranks } \\
\text { Positive ranks } \\
\text { Equals } \\
\text { total }\end{array}$ & $\begin{array}{c}2 \\
38 \\
0 \\
41\end{array}$ & $\begin{array}{c}4.33 \\
22.32\end{array}$ & $\begin{array}{c}13 \\
848\end{array}$ & -5.41 & 0.000 \\
\hline & $\begin{array}{l}\text { Difference of created } \\
\text { association on } \\
\text { Iranian and Korean } \\
\text { brand }\end{array}$ & $\begin{array}{l}\text { Negative ranks } \\
\text { Positive ranks } \\
\text { Equals } \\
\text { total }\end{array}$ & $\begin{array}{c}2 \\
39 \\
0 \\
41 \\
\end{array}$ & $\begin{array}{c}1.50 \\
22.00\end{array}$ & $\begin{array}{c}3 \\
858\end{array}$ & -5.54 & 0.000 \\
\hline & $\begin{array}{l}\text { Difference of image } \\
\text { on Iranian and } \\
\text { Korean brand }\end{array}$ & $\begin{array}{l}\text { Negative ranks } \\
\text { Positive ranks } \\
\text { Equals } \\
\text { total }\end{array}$ & $\begin{array}{c}1 \\
40 \\
0 \\
41 \\
\end{array}$ & $\begin{array}{c}2 \\
21.48\end{array}$ & $\begin{array}{c}2 \\
859\end{array}$ & -5.553 & 0.000 \\
\hline & $\begin{array}{l}\text { Difference of loyalty } \\
\text { to Iranian and } \\
\text { Korean brand }\end{array}$ & $\begin{array}{l}\text { Negative ranks } \\
\text { Positive ranks } \\
\text { Equals } \\
\text { total }\end{array}$ & $\begin{array}{c}2 \\
39 \\
0 \\
41\end{array}$ & $\begin{array}{l}1.5 \\
22\end{array}$ & $\begin{array}{c}3 \\
858\end{array}$ & -5.541 & 0.000 \\
\hline & $\begin{array}{l}\text { Difference of } \\
\text { tendency to extra } \\
\text { payment for Iranian } \\
\text { and Korean brand }\end{array}$ & $\begin{array}{l}\text { Positive ranks } \\
\text { Positive ranks } \\
\text { Equals } \\
\text { total }\end{array}$ & $\begin{array}{c}4 \\
36 \\
1 \\
41\end{array}$ & $\begin{array}{c}9.5 \\
21.72\end{array}$ & $\begin{array}{c}38 \\
782\end{array}$ & -5.002 & 0.000 \\
\hline \multirow{5}{*}{ 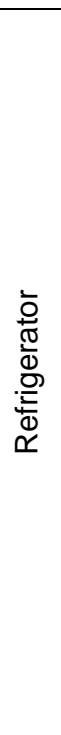 } & $\begin{array}{l}\text { Difference of attitude } \\
\text { on Iranian and } \\
\text { Korean brand }\end{array}$ & $\begin{array}{l}\text { Negative ranks } \\
\text { Positive ranks } \\
\text { Equals } \\
\text { total }\end{array}$ & $\begin{array}{c}0 \\
68 \\
0 \\
68\end{array}$ & $\begin{array}{c}0 \\
34.5\end{array}$ & $\begin{array}{c}0 \\
2346\end{array}$ & -7.167 & 0.000 \\
\hline & $\begin{array}{l}\text { Difference of created } \\
\text { association on } \\
\text { Iranian and Korean } \\
\text { brand }\end{array}$ & $\begin{array}{l}\text { Negative ranks } \\
\text { Positive ranks } \\
\text { Equals } \\
\text { total }\end{array}$ & $\begin{array}{c}1 \\
67 \\
0 \\
68\end{array}$ & $\begin{array}{c}7 \\
34.91\end{array}$ & $\begin{array}{c}7 \\
2339\end{array}$ & -7.125 & 0.000 \\
\hline & $\begin{array}{l}\text { Difference of image } \\
\text { on Iranian and } \\
\text { Korean brand }\end{array}$ & $\begin{array}{l}\text { Negative ranks } \\
\text { Positive ranks } \\
\text { Equals } \\
\text { total }\end{array}$ & $\begin{array}{c}0 \\
68 \\
0 \\
68 \\
\end{array}$ & $\begin{array}{c}0 \\
34.5\end{array}$ & $\begin{array}{c}0 \\
2346\end{array}$ & -7.167 & 0.000 \\
\hline & $\begin{array}{l}\text { Difference of loyalty } \\
\text { to Iranian and } \\
\text { Korean brand }\end{array}$ & $\begin{array}{l}\text { Negative ranks } \\
\text { Positive ranks } \\
\text { Equals } \\
\text { total }\end{array}$ & $\begin{array}{c}0 \\
68 \\
0 \\
68 \\
\end{array}$ & $\begin{array}{c}0 \\
34.5\end{array}$ & $\begin{array}{c}0 \\
2346\end{array}$ & -7.168 & 0.000 \\
\hline & $\begin{array}{l}\text { Difference of } \\
\text { tendency to extra } \\
\text { payment for Iranian } \\
\text { and Korean brand }\end{array}$ & $\begin{array}{l}\text { Positive ranks } \\
\text { Positive ranks } \\
\text { Equals } \\
\text { total }\end{array}$ & $\begin{array}{c}6 \\
62 \\
0 \\
68 \\
\end{array}$ & $\begin{array}{c}6.67 \\
37.19\end{array}$ & $\begin{array}{c}40 \\
2306\end{array}$ & -6.925 & 0.000 \\
\hline \multirow{2}{*}{ 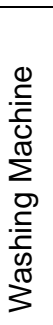 } & $\begin{array}{l}\text { Difference of attitude } \\
\text { on Iranian and } \\
\text { Korean brand }\end{array}$ & $\begin{array}{l}\text { Negative ranks } \\
\text { Positive ranks } \\
\text { Equals } \\
\text { total }\end{array}$ & $\begin{array}{c}21 \\
62 \\
1 \\
84 \\
\end{array}$ & $\begin{array}{l}22.45 \\
48.62\end{array}$ & $\begin{array}{c}471.5 \\
3014.5\end{array}$ & -5.773 & 0.000 \\
\hline & $\begin{array}{l}\text { Difference of created } \\
\text { association on } \\
\text { Iranian and Korean } \\
\text { brand }\end{array}$ & $\begin{array}{l}\text { Negative ranks } \\
\text { Positive ranks } \\
\text { Equals } \\
\text { total }\end{array}$ & $\begin{array}{c}8 \\
76 \\
0 \\
84\end{array}$ & $\begin{array}{l}26.31 \\
44.20\end{array}$ & $\begin{array}{c}210.5 \\
3359.5\end{array}$ & -7.022 & 0.000 \\
\hline
\end{tabular}


Am. J. Sci. Ind. Res., 2011, 2(5): 786-797

\begin{tabular}{|c|c|c|c|c|c|c|c|}
\hline & $\begin{array}{l}\text { Difference of image } \\
\text { on Iranian and } \\
\text { Korean brand }\end{array}$ & $\begin{array}{l}\text { Negative ranks } \\
\text { Positive ranks } \\
\text { Equals } \\
\text { total }\end{array}$ & $\begin{array}{c}3 \\
71 \\
0 \\
84\end{array}$ & $\begin{array}{l}21.23 \\
46.39\end{array}$ & $\begin{array}{c}276 \\
3294\end{array}$ & -6.73 & 0.000 \\
\hline & $\begin{array}{l}\text { Difference of loyalty } \\
\text { to Iranian and } \\
\text { Korean brand }\end{array}$ & $\begin{array}{l}\text { Negative ranks } \\
\text { Positive ranks } \\
\text { Equals } \\
\text { total }\end{array}$ & $\begin{array}{c}20 \\
63 \\
1 \\
84\end{array}$ & $\begin{array}{l}31.62 \\
45.29\end{array}$ & $\begin{array}{c}632.5 \\
2853.5\end{array}$ & -5.043 & 0.000 \\
\hline & $\begin{array}{l}\text { Difference of } \\
\text { tendency to extra } \\
\text { payment for Iranian } \\
\text { and Korean brand }\end{array}$ & $\begin{array}{l}\text { Positive ranks } \\
\text { Positive ranks } \\
\text { Equals } \\
\text { total }\end{array}$ & $\begin{array}{c}31 \\
49 \\
4 \\
84\end{array}$ & $\begin{array}{l}41.65 \\
39.78\end{array}$ & $\begin{array}{l}1291 \\
1949\end{array}$ & -1.578 & 0.000 \\
\hline \multirow{5}{*}{ 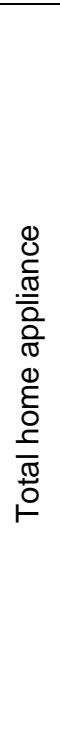 } & $\begin{array}{l}\text { Difference of attitude } \\
\text { on Iranian and } \\
\text { Korean brand }\end{array}$ & $\begin{array}{l}\text { Negative ranks } \\
\text { Positive ranks } \\
\text { Equals } \\
\text { total }\end{array}$ & $\begin{array}{c}29 \\
163 \\
1 \\
193\end{array}$ & $\begin{array}{c}36.67 \\
107.14\end{array}$ & $\begin{array}{r}1063.5 \\
17464.5\end{array}$ & -10.636 & 0.000 \\
\hline & $\begin{array}{l}\text { Difference of created } \\
\text { association on } \\
\text { Iranian and Korean } \\
\text { brand }\end{array}$ & $\begin{array}{l}\text { Negative ranks } \\
\text { Positive ranks } \\
\text { Equals } \\
\text { total }\end{array}$ & $\begin{array}{c}11 \\
182 \\
0 \\
193\end{array}$ & $\begin{array}{c}39.5 \\
100.48\end{array}$ & $\begin{array}{c}434.5 \\
18286.5\end{array}$ & -11.488 & 0.000 \\
\hline & $\begin{array}{l}\text { Difference of image } \\
\text { on Iranian and } \\
\text { Korean brand }\end{array}$ & $\begin{array}{l}\text { Negative ranks } \\
\text { Positive ranks } \\
\text { Equals } \\
\text { total }\end{array}$ & $\begin{array}{c}13 \\
180 \\
0 \\
193 \\
\end{array}$ & $\begin{array}{l}34.69 \\
101.5\end{array}$ & $\begin{array}{c}451 \\
18270\end{array}$ & -11.466 & 0.000 \\
\hline & $\begin{array}{l}\text { Difference of loyalty } \\
\text { to Iranian and } \\
\text { Korean brand }\end{array}$ & $\begin{array}{l}\text { Negative ranks } \\
\text { Positive ranks } \\
\text { Equals } \\
\text { total }\end{array}$ & $\begin{array}{c}22 \\
170 \\
1 \\
193\end{array}$ & $\begin{array}{c}51.86 \\
102.28\end{array}$ & $\begin{array}{c}1141 \\
17387\end{array}$ & -10.536 & 0.000 \\
\hline & $\begin{array}{l}\text { Difference of } \\
\text { tendency to extra } \\
\text { payment for Iranian } \\
\text { and Korean brand }\end{array}$ & $\begin{array}{l}\text { Positive ranks } \\
\text { Positive ranks } \\
\text { Equals } \\
\text { total }\end{array}$ & $\begin{array}{c}41 \\
147 \\
5 \\
193\end{array}$ & $\begin{array}{c}74.15 \\
100.18\end{array}$ & $\begin{array}{c}3040 \\
14726\end{array}$ & -7.822 & 0.000 \\
\hline
\end{tabular}

As seen in table 2, the result of Wilcoxon test on research minor hypotheses is as follows:

(1) H1: attitude on Iranian home appliance brand equities is lower than Korean ones in terms of quality.

Test result: calculated $Z$ on the difference between attitudes on all three products of refrigerator, TV set and washing machine as well as total home appliance is in the refusal area of null hypothesis at 0.05 of determination level ( $95 \%$ confidence). So, the first minor hypothesis is supported by $95 \%$ confidence level.

(2) H2: association on Iranian home appliance brand equities is lower than Korean ones in terms of utility.

Test result: calculated $Z$ on the difference between association on all three products of refrigerator, TV set and washing machine as well as total home appliance is in the refusal area of null hypothesis at 0.05 of determination level ( $95 \%$ confidence). So, the second minor hypothesis is supported by $95 \%$ confidence level.

(3) H3: the image of Iranian home appliance brand equities is lower than Korean ones in terms of perceived quality.

Test result: calculated $Z$ on the difference between the images of all three products of refrigerator, TV set and washing machine as well as total home appliance is in the refusal area of null hypothesis at 0.05 of determination level ( $95 \%$ confidence). So, the third minor hypothesis is supported by $95 \%$ confidence level.

(4) H4: loyalty to Iranian home appliance brand equities is lower than Korean ones.

Test result: calculated $Z$ on the difference between loyalty to all three products of refrigerator, TV set and washing machine as well as total home appliance is in the refusal area of null hypothesis at 0.05 of determination level (95\% confidence). So, the fourth 
minor hypothesis is supported by $95 \%$ confidence level.

(5) H5: tendency to extra payment for Iranian home appliance brand equities is lower than Korean ones in terms of utility.

Test result: calculated $Z$ on the difference between tendency to extra payment for two products of refrigerator and TV set is in the refusal area of null hypothesis at 0.05 of determination level $(95 \%$ confidence) while it is in the supporting area of $\mathrm{HO}$ for washing machine. Regarding total home appliance, it is in the refusal area of $\mathrm{HO}$. So, the fifth minor hypothesis is supported by $95 \%$ confidence level.
Research major hypothesis test: Major hypothesis: the hidden value of Iranian home appliance brand equities is lower than Korean ones.

The results of Wilcoxon test on above hypothesis are outlined in table 3 .

As seen in table3, statistical null hypothesis is refused in all four tests at 0.05 of determination level. Therefore, research major hypothesis on the low Iranian brand equities for TV sets, refrigerators, washing machine and total home appliance compared to Korean ones is supported.

Ranking brand equity in terms of products: Freedman's test was used to rank brand equity. Test results and the rank of each brand equity for all three studied products are shown in table 4 .

Table 3: the results of Wilcoxon test and its statistic on research major hypothesis for all three products and total home appliance

\begin{tabular}{|c|c|c|c|c|c|c|c|}
\hline & Hypotheses & Korea-Iran & $\begin{array}{c}\text { Quantit } \\
y\end{array}$ & $\begin{array}{l}\text { Average } \\
\text { rate }\end{array}$ & $\begin{array}{l}\text { Total } \\
\text { ranks }\end{array}$ & $\mathbf{Z}$ & $\begin{array}{l}\text { Asymp. Sig. (2- } \\
\text { tailed) }\end{array}$ \\
\hline \multirow{4}{*}{ 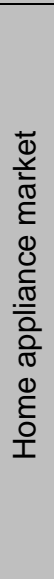 } & $\begin{array}{l}\text { The difference of brand } \\
\text { equity between iranian } \\
\text { and Korean on TV sets }\end{array}$ & $\begin{array}{l}\text { Negative ranks } \\
\text { Positive ranks } \\
\text { Equals } \\
\text { total }\end{array}$ & $\begin{array}{c}2 \\
39 \\
0 \\
41\end{array}$ & $\begin{array}{l}15 \\
22\end{array}$ & $\begin{array}{c}4 \\
858\end{array}$ & -5.540 & 0.000 \\
\hline & $\begin{array}{l}\text { The difference of brand } \\
\text { equity between Iranian } \\
\text { and Korean on } \\
\text { refrigerators }\end{array}$ & $\begin{array}{l}\text { Negative ranks } \\
\text { Positive ranks } \\
\text { Equals } \\
\text { total }\end{array}$ & $\begin{array}{c}0 \\
68 \\
0 \\
68\end{array}$ & $\begin{array}{c}0 \\
34.5\end{array}$ & $\begin{array}{c}0 \\
2346\end{array}$ & -7.167 & 0.000 \\
\hline & $\begin{array}{l}\text { The difference of brand } \\
\text { equity between Iranian } \\
\text { and Korean on washing } \\
\text { machines }\end{array}$ & $\begin{array}{l}\text { Negative ranks } \\
\text { Positive ranks } \\
\text { Equals } \\
\text { total }\end{array}$ & $\begin{array}{c}20 \\
64 \\
0 \\
82\end{array}$ & $\begin{array}{l}22.10 \\
28.88\end{array}$ & $\begin{array}{c}442 \\
3128\end{array}$ & -5.989 & 0.000 \\
\hline & $\begin{array}{l}\text { The difference of brand } \\
\text { equity between Iranian } \\
\text { and Korean overall }\end{array}$ & $\begin{array}{l}\text { Negative ranks } \\
\text { Positive ranks } \\
\text { Equals } \\
\text { total }\end{array}$ & $\begin{array}{c}22 \\
171 \\
0 \\
193\end{array}$ & $\begin{array}{c}30.23 \\
105.59\end{array}$ & $\begin{array}{c}665 \\
18056\end{array}$ & -11.191 & 0.000 \\
\hline
\end{tabular}


Table 4: the results of Freedman's test and brand equity ranking in all three studied products

\begin{tabular}{|c|c|c|c|c|c|c|}
\hline \multirow[b]{2}{*}{$\begin{array}{l}\text { 음 } \\
\text { 음 }\end{array}$} & \multirow{2}{*}{ Brand } & \multirow{2}{*}{ Quantity } & \multirow{2}{*}{ Average } & \multirow{2}{*}{ Standard deviation } & \multirow{2}{*}{ Average rank } & \multirow{2}{*}{ Priority } \\
\hline & & & & & & \\
\hline \multirow{7}{*}{ 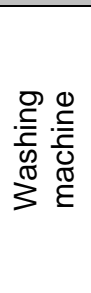 } & LG & 84 & 5.512 & 0.950 & 4.79 & 1 \\
\hline & Samsung & 84 & 5.379 & 0.900 & 4.63 & 2 \\
\hline & Daewoo & 84 & 4.440 & 1.061 & 3.04 & 4 \\
\hline & Absal & 84 & 4.853 & 1.058 & 3.62 & 3 \\
\hline & Pakshuma & 84 & 4.310 & .0950 & 3.62 & 5 \\
\hline & Snowa & 84 & 4.020 & 1.093 & 2.30 & 6 \\
\hline & Statistical test & \multicolumn{5}{|c|}{$N=84, d f=5, \operatorname{Sig}=0.000, x^{2}=129.728$} \\
\hline \multirow{7}{*}{ 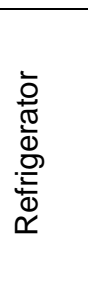 } & LG & 68 & 5.733 & 0.947 & 5.23 & 1 \\
\hline & Samsung & 68 & 5.684 & 0.938 & 5.05 & 2 \\
\hline & Daewoo & 68 & 4.927 & 0.964 & 3.97 & 3 \\
\hline & Emersun & 68 & 3.796 & 1.072 & 2.41 & 5 \\
\hline & Yakhsaran & 68 & 3.222 & 1.066 & 1.57 & 6 \\
\hline & Snowa & 68 & 4.056 & 1.156 & 2.76 & 4 \\
\hline & Statistical test & \multicolumn{5}{|c|}{$N=68, d f=5, \operatorname{Sig}=0.000, x^{2}=215.419$} \\
\hline \multirow{7}{*}{$\begin{array}{l}-\mathbb{D} \\
\infty \\
\stackrel{\infty}{Z}\end{array}$} & LG & 41 & 5.599 & 0.858 & 4.96 & 2 \\
\hline & Samsung & 41 & 5.808 & 0.802 & 5.52 & 1 \\
\hline & Daewoo & 41 & 4.527 & 1.149 & 3.27 & 3 \\
\hline & Pars & 41 & 3.441 & 1.279 & 1.94 & 6 \\
\hline & Sanam & 41 & 4.037 & 1.197 & 2.61 & 5 \\
\hline & Snowa & 41 & 3.970 & 1.283 & 2.70 & 4 \\
\hline & Statistical test & \multicolumn{5}{|c|}{$\mathrm{N}=41, \mathrm{df}=5, \mathrm{Sig}=0.000, \mathrm{x}^{2}=119.807$} \\
\hline
\end{tabular}

As seen in table 4 , calculate chi-square (x2) for all three products is significant at freedom degree 5 and 0.05 of determination level. So, statistical null hypothesis regarding non difference between the ranks of brand equities for all three products is refused with $95 \%$ probability. Therefore, brand equities are ranked in above table based on ranks average.
Path Analysis the differences between Iranian and Korean brand equity based on regression model

To observe the impacts of differences between research model variables on the brand equityof Iranian and Korean products, a path analysis diagram was drawn. Its structural equations include:

\begin{tabular}{|l|l|}
\hline \multicolumn{1}{|c|}{ Title } & \multicolumn{1}{c|}{ Structure equation } \\
\hline different attitudes on brand & $X_{1}=0.167+0.389 X_{11}+0.270 X_{12}+0.149 X_{13}$ \\
\hline different images on brand & $X_{2}=-7.739+0.5 X_{1}+0.5 X_{3}$ \\
\hline different associations on brand & $X_{3}=0.631+0.162 X_{31}+0.063 X_{32}+0.325 X_{33}$ \\
\hline different brand equity & $Y=1.468+0.127 X_{3}-0.4 X_{2}+0.029 X_{4}+.076 X_{5}$ \\
\hline
\end{tabular}

Then partial standardized regression coefficient $(\beta)$ was used as path ratio to achieve the direct and indirect impacts of each independent variable on depended variables. Since these ratios are standardized in path analysis diagram, one can compare the impacts of different variables and then determine the most effective one. On this basis, the highest impact in expressing the difference between Iranian and Korean brand equity is the difference 
between the tendencies to extra payment for Iranian ad Korean brand which is 0.112 . It follows by difference in loyalty to brand is the second impacting factor with 0.039 value in the emergence of difference between Iranian and Korean brand equity. It also follows by difference on created associations with total -0.076 value, difference on attitude to brand with total -0.211 value and finally difference on perceived image of brand with -0.355 value cause the difference between the Iranian and Korean brand equities

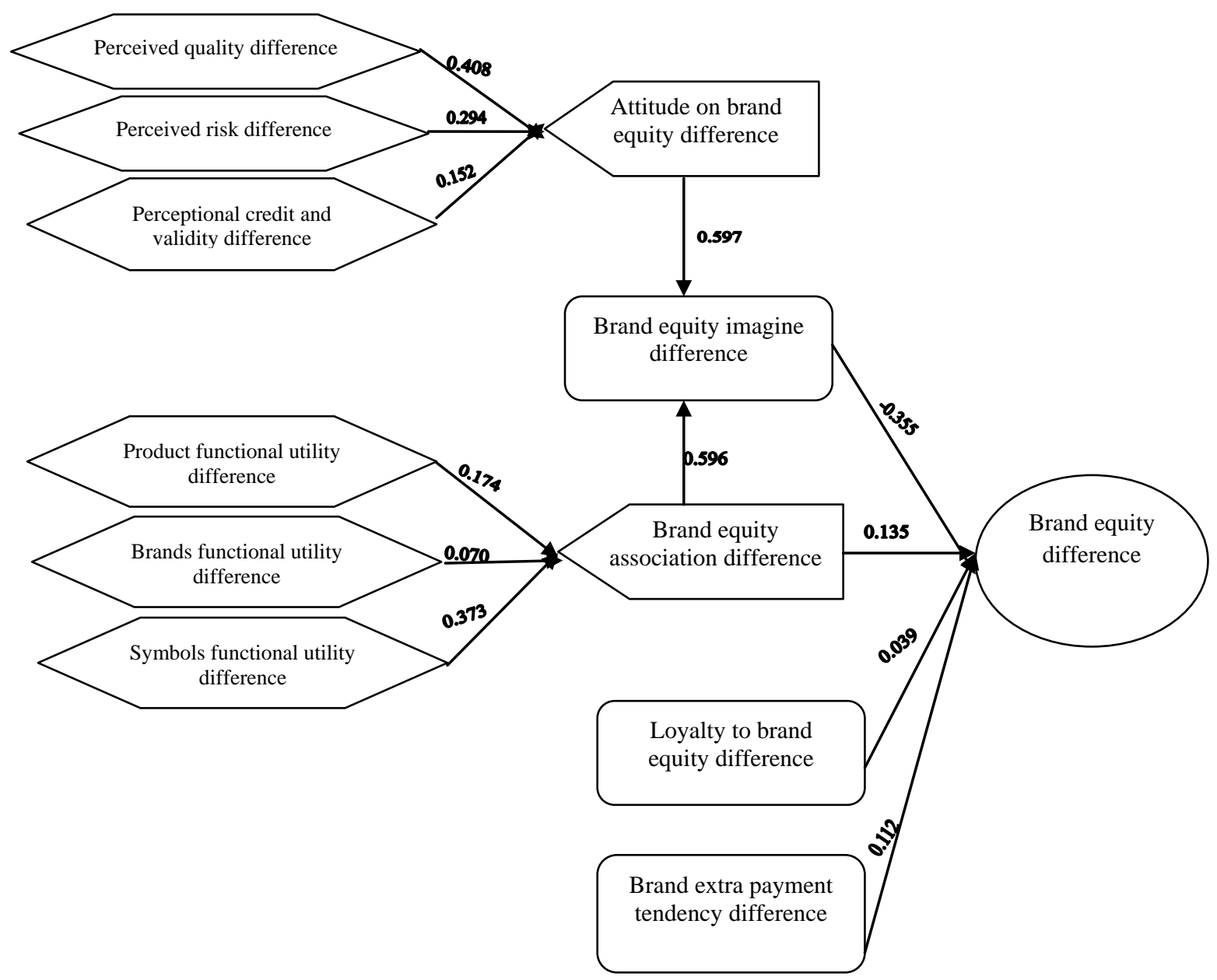

Fig 3. Path analysis diagram of equity difference of Iranian and Korean brand

\section{CONCLUSION AND SUGGESTIONS}

This research titled "evaluating and comparing Iranian and Korean home appliance brand equity in the view of Tehran Bazaar retailers" is based on the aim of investigating the differences between five perceptional and behavioral model factors. Therefore, one major hypothesis and five minor ones were devised which all were confirmed by Wilcoxon test. Based on supported hypotheses, one can conclude that Korean brand equities have been able better than Iranian ones to create a perception in home appliance market that Korean products have good quality, low risk, higher credit and better attitude than Iranian brand. A reason for Korean brand better association than Iranian ones is due to the perception of market aesthetic, customers' satisfaction, accountability to promises, honest advertisements, using varied and updated models, utilizing state-ofthe-art technologies and so on which have huge differences with Iranian brand equities. 
Shaping and loyalty to brand is a variable by which Korean firms have been able to have better performance than Iranian firms and use its strategic advantages.

The fact that customers' tendency to extra payment for Korean washing machines is similar to Iranian washing machines shows that regarding washing machine, Iranian brand has become close to Korean washing machines compared to other two products and have been able to decrease the distance between both products. Regarding other two products, Korean brand equities have become closer to consumers' tastes more than Iranian ones and they are more tended to extra payment for Korean products.

The results show that Korean brand equities have been able to penetrate households' baskets and market showcase and have more equity in terms of market and more market share.

Anyhow, the concept of brand equity is obtained via consumers' perceptions. Therefore, manufacturers should attempt toward shaping, directing and stabilizing a proper perception of brand equity in customer's mind. In this line, they should improve those effective factors on brand equity enhancement and avoid those factors which weaken this value. Research model indicates variables which impact on brand equity directly and indirectly. Therefore, brand manufacturers should focus on such variables in order to establish strong brand equity and/or enhance their brand equity. Enhancing the characteristics of production, supply and sale of products by considering the aspects of brand equity is a guideline.

\section{REFERENCES}

Aaker, david(2006)," strategic management of market", translated by hossein safarzadeh \& aliakbar farhangi, Tehran, poyesh publication.

Aaker,David.A and Keller,Kevin Lane(1993), "Interpreting cross-cultural replications of brand extension research" Intern.J. of research in marketing, No.10, pp.55-59.

Agarwal,M.K. and Rao,V.R.(1996), "An empirical comparison of consumer based brand equity " Marketing letters, Vol.7 No3, pp.237-270.

Bahreinizadeh, manigeh(2006)," a model for valuation of brand by the consumer's approached", thesis for ph.d, by directed hossein rahman seresht, Tehran, accountant and management college, allameh tabatabaye university.
Baldauf. Artur, Cravens. KarenS, Diamantopoulos. Adamantios, Zeugner. Katharina Petra,(2009) " The Impact of Product-Country Image and Marketing Efforts on Retailer-Perceived Brand Equity: An Empirical Analysis " Journal of Retailing, No.85, vol.4, pp.437-452.

Bekhradi, farshad(2009)," presentation of a model for measure the associations of brand in alimentary industry", thesis for senior graduate, by directed aliakbar farhangi, Tehran, management college, Tehran university.

Broun, tom(2007)" the philosophy of brand" translated by atteih bathayie, Tehran, fara publication.

Cavusgil. Erin(2008), "Three Essays on Marketing Strategies Elements And The Brand Life Cycles in The Pharmaceutical Industry" thesis for the degree of Doctor PH.d, directed by Dr. Roger Calantone, Department of Marketing, Michigan State University, USA.

Chen.Ching-Fu,Chang.Yu-Ying (2008), "Airline brand equity , brand preference, and purchase intentions - the moderating effects of switching cost" Journal of Air Transport Management ,Vol.3,No.14,pp.40-42.

Chunling. YU, Ping. ZHAO, Haizhong. WANG,(2008), "An empirical evaluation of a customer-based brand" Journal of Marketing Science, No.2, Vol.4, pp.553570 .

Cupferer jan noeal(2006)," brand strategic management", translated by sina ghorbanlo, Tehran, moballeghan publication.

Davis.Donna.F, Mentzer.John.T(2008), "Relational Resources in Interorganizational Exchange:The Effects of Trade Equity and Brand Equity"Journal of Retailing,Vol.14, No.84,pp.435-448 .

Kalantari, khalile,(2010)," process and analyze the datas in economic- society research", Tehran, farhange saba publication.

Keller,K.L.(1993),"Conceptualizing, measuring and managing customer based brand eqity " Journal of marketing, Vol.57 jonuary, pp.1-22.

Laboy, Pedro(2005), "The Importance of Measuring Brand Value and Brand Equity "www.Tocquigny.com,pp.1-8.

Rahman seresht, hossein, Bahreinizadeh, manigeh(2006), )," a model for valuation of brand by the consumer's approached" journal of elome of iran management, vol.1, no.4, pp.29-53.

Seyyed javadein, seyyed reza, shams, rahill(2007)," determinants of brand equity of sport shoes in middle youth age group", humanism and social bulletin, vol.7, no.25, pp.73-96. 
Simon, C.J. and Sullivan, M.W.(1993), "The measurement and determinants of brand equity: a financial approach“, Marketing Science,Vol.12, No.1, pp.28-53 .

Slotegraaf. Rebecca J, Pauwels. Koen(2008) "The Impact of Brand Equity and Innovation on the Long-Term Effectiveness of Promotions" Journal of Marketing Research, Vol. XLV, pp.293-306.

Temporal, paoel(2003)," brand in asia", translated by mohammad ebrahim goharian, Tehran, amirkabir publication.
Tong. Xiao, Hawley. Jana M,(2009) "Measuring Customer Based Brand Equity: Empirical Evidence from the Sportswear Market in China" Journal of Product \& Brand Management, Vol.18, No.4, pp.262-271.

Vafanejad, saeed(2008)" survey of brand equity and its relation with customer purchase behavior and decision making", thesis for senior graduate, by directed haghighi mohammad, qom, management college, Tehran university. 